\title{
PENINGKATAN KAPASITAS GURU PAI MELALUI PELATIHAN MODIFIKASI KURIKULUM MENGGUNAKAN DIFFERENTIATED INSTRUCTION UNTUK SISWA DISABILITAS INTELEKTUAL
}

\author{
Anita Aisah $^{1}$, Dwi Santosa ${ }^{2}$ \\ ${ }^{1}$ Fakultas Agama Islam Universitas Muhammadiyah Yogyakarta, Email : aisahanita@gmail.com \\ ${ }^{2}$ Fakultas Agama Islam Universitas Muhammadiyah Yogyakarta
}

\begin{abstract}
ABSTRAK
Penelitian ini bertujuan untuk menguji efektifitas pelatihan modifikasi kurikulum differentiated instruction pada pendidikan agama islam (pai) untuk siswa disabilitas intelektual. Latar belakang masalah dalam penelitian ini ada ketidaksiapan guru PAI dalam menghadapi keberagaman siswa terutama pada aspek keberagaman mental. Peneliti mengambil tema siswa disabilitas intelektual berdasarkan studi pendahuluan yang menghasilkan bahwa banyak siswa dengan karakteristik disabilitas intelektual ditemui oleh guru PAI. Differentiatied Instruction dipilih karena sudah terbukti efektif digunakan di dalam kelas dengan keberagaman siswa. Penelitian ini menggunakan metode eksperimen pretest posttest kontrol grup design. Alat ukur yang digunakan adalah angket terbuka pretest dan posttest untuk menguji pengetahuan peserta pelatihan tentang modifikasi kurikulum differentiated instruction pada mapel PAI untuk siswa disabilitas intelektual. Alat pengambil data selain angket adalah blanko observasi. Observasi dilakukan untuk mengetahui ketrampilan memodifikasi kurikulum pada peserta selama pelatihan berlangsung. Pelatihan telah dilaksanakan pada bulan Juli 2018 di Fakultas Agama Islam Universitas Muhammadiyah Yogyakarta. Ada 19 peserta dengan karakteristik pendidik PAI yang sudah memiliki pengalaman mengajar minimal 1 tahun. Hasil dari penelitian ini adalah adanya perbedaan yang signifikan antara pretest dan posttest pengetahuan tentang modifikasi kurikulum differentiated instruction pada mapel PAI untuk siswa disabilitas intelektual. Perbedaan ini ditunjukkan oleh skor signifikansi $0,00(0,00<0,05)$. Hasil yang lain adalah ketrampilan peserta yang sudah mengikuti langkah langkah dalam menerapkan DI khususnya pada RPP. Kelemahan dari pelatihan ini adalah waktu yang sangat terbatas terutama pada sesi praktik implementasi differentiated instruction pada RPP yang disediakan sehingga pembuatan evaluasi pada RPP tidak dirinci lebih detail.
\end{abstract}

Kata kunci: Modifikasi; Kurikulum Differentiated Instruction; PAI; Disabilitas Intelektual.

\begin{abstract}
This study aims to test the effectiveness of differentiated instruction curriculum modification training onPendidikan Agama Islam (PAI) subjects for students with intellectual disabilities. The background of the problem in this study is the unpreparedness of PAI teachers in facing the diversity of students, especially in aspects of mental diversity. The researcher took the theme of intellectual disability students based on a preliminary study which resulted that many students with characteristics of intellectual disability were met by PAI teachers. Differentiated Instruction is chosen because it has been proven to be effectively used in the classroom with diversity of students. This study used the experimental method pretest posttest group control design. The measuring instrument used was an open questionnaire pretest and posttest to test the training participants' knowledge about the modification of the differentiated instruction curriculum in PAI subjects for students with intellectual disabilities. Data retrieval tool other than questionnaire is an observation form. Observations were made to find out skills in modifying the curriculum to participants during the training. The training was held on July 19, 2018 at the Faculty of Islamic Studies, Muhammadiyah University, Yogyakarta. There were 19 participants with the characteristics of PAI educators who had at least 1 year of teaching experience. The results of this study were significant differences between the pretest and posttest knowledge of the modified differentiated instruction curriculum in the PAI model for students with intellectual disabilities. This difference is indicated by a significance score of $0.00(0.00<0.05)$.
\end{abstract}


Another result is the skills of participants who have followed the steps in implementing DI especially in RPP. The disadvantage of this training is that the time is very limited, especially in the differentiated instruction implementation practice session in the RPP provided so that the evaluation in the lesson plan is not detailed in more detail.

Keywords: Modification; Curriculum Differentiated Instruction; PAI; Intellectual Disability.

\section{PENDAHULUAN}

Pendidikan merupakan hak semua warga negara Indonesia. Salah satu Pendidikan di Indonesia adalah Pendidikan Agama Islam. Menurut Syarifudin dkk (Fitriani, 2013), Pendidikan Agama Islam (PAI) termasuk salah satu pendidikan yang penting karena dengan adanya PAI maka tujuan pendidikan nasional akan tercapai. Salah satu tujuan pendidikan nasional adalah mewujudkan peserta didik yang beriman dan bertaqwa kepada Tuhan YME (Tafsir, 2010). Pendidikan agama Islam dimasukkan sebagai mata pelajaran wajib pada setiap jenjang pendidikan. Pendidikan agama Islam adalah pendidikan yang memberikan pengetahuan, membentuk sikap, kepribadian dan keterampilan peserta didik dalam mengamalkan ajaran agama. Dalam kurikulum 2013, mata pelajaran PAI digabung dengan Budi Pekerti. Mata pelajaran PAI dan Budi Pekerti diajarkan selama 4 jam per minggu di Sekolah Dasar dan 3 jam di Sekolah Menengah.

Semua warga negara termasuk anak berkebutuhan khusus berhak mendapatkan layanan berupa Pendidikan Agama Islam dan Budi Pekerti (UU No. 20 tahun 2003 tentang Sistem Pendidikan Nasional). Namun berdasarkan studi pendahuluan yang dilakukan oleh peneliti, pendidik PAI di sekolah reguler belum memiliki kompetensi untuk mengajar siswa yang berkebutuhan khusus. Kurikulum PAI tidak disesuaikan dengan keberagaman siswa. Berdasarkan asesmen peneliti di sekolah inklusi maupun sekolah reguler, guru Agama Islam tidak dibekali ilmu untuk mengajar siswa berkebutuhan khusus. Guru Agama Islam di Sekolah inklusi mengajar agama islam secara klasikal. Proses mentransfer pengetahuan kepada siswa berkebutuhan khusus melalui guru pendamping inklusi, sehingga tidak ada masalah. Namun akan terjadi masalah apabila siswa berkebutuan khusus tersebut tidak memiliki pendamping untuk membantu proses belajarnya di kelas.

Berdasarkan hasil studi pendahuluan melalui observasi dan wawancara pada saat mendampingi mahasiswa Praktek Pengalaman Lapangan baik di Sekolah Dasar maupun Menengah Atas Muhammadiyah di Yogyakarta pada tahun 2015-2016. Metode pengajarannya dilaksanakan secara klasikal. Ada beberapa guru yang membuat teknik penyampaiannya menarik seperti menggunakan video saat belajar sejarah Islam, memberikan reward bagi siswa yang berprestasi menghafal surat-surat pendek dan pembiasaan sholat berjamaah di Sekolah. Peneliti juga pernah melakukan praktik profesi psikologi di Sekolah Inklusi di Yogyakarta pada tahun 2012-2013. Hasil observasi peneliti pada sekolah pada siswa muslim yang 
ABK mengikuti pembelajaran agama secara klasikal oleh guru Agama Islam. Guru pendamping yang mendampingi siswa berkebutuhan khusus tidak memiliki riwayat pendidikan khusus agama islam.

Riset awal dilakukan peneliti melalui wawancara peserta Praktek Pengalaman Lapangan (PPL) Prodi PAI angkatan 2014, terdapat sekitar minimal 10 persen siswa di kelas yang mengalami kesulitan belajar seperti kesulitan memahami instruksi guru sehingga skor akhirnya di bawah rata-rata skor kelas. Jenis keberagaman siswa di kelas ditinjau dari beberapa aspek. Namun gangguan yang paling banyak terlihat di kelas adalah gangguan kognitif. Hal ini didukung oleh pernyataan Admila (2018) seorang ahli inklusi, bahwa keberagaman siswa yang paling sering ditemui ditinjau dari aspek kognitif. Keberagaman siswa ditinjau dari aspek kognitif terdiri dari beberapa kategori yaitu siswa genius, siswa di atas rata-rata, siswa rata-rata, siswa di bawah rata-rata/boderdline dan intellectual disabilities (Berkowitz, 2009). Pembelajaran yang dilakukan secara klasikal ini menggunakan kurikulum yang sama, padahal karakteristik siswanya beragam. Hasil dari observasi yang dilakukan oleh peneliti pada dua Rencana Pembelajaran Strategis mata kuliah kurikulum PAI di salah satu universitas swasta di Yogyakarta, tidak ada materi bagaimana memodifikasi kurikulum PAI bagi siswa berkebutuhan khusus. Calon guru PAI belum dibekali ilmu bagaimana melakukan asesmen dan membuat kurikulum PAI untuk siswa yang beragam. Ketrampilan memodifikasi kurikulum sangat dibutuhkan oleh guru PAI dalam menghadapi keberagaman siswa.

Hasil riset awal peneliti juga didukung oleh beberapa hasil penelitian. Penelitian dilakukan oleh Pramuji (2015) di sekolah inklusi di Purwokerto. Hasil penelitian Pramuji adalah siswa berkebutuhan khusus memiliki guru pendamping tetapi proses belajar mata pelajaran PAI tetap dilakukan secara klasikal menggunakan kurikulum yang sama. Hal ini karena guru PAI hanya ada satu di sekolah tersebut dan guru tersebut tidak memiliki dasar ilmu bagaimana memodifikasi kurikulum. Berdasarkan hasil penelitian oleh Hamun (2014) tentang metode pembelajaran PAI di SLB Kota Langsa yaitu belum maksimalnya guru PAI dalam mengajar ABK dan minimnya buku pegangan PAI bagi ABK.

Metode pengajarannya masih dilaksanakan secara klasikal. Berdasarkan observasi Hanum (2014), banyak siswa yang terlihat pasif pada proses pembelajaran PAI di kelas. Hanum (2014) memberikan saran pada hasil penelitiannya supaya ada pelatihan khusus bagi guru PAI dalam mendidik ABK. Berdasarkan pemaparan di atas, peneliti menawarkan sebuah pelatihan metode modifikasi kurikulum pada mapel PAI untuk siswa Intelectual Disability. Karakter siswa intellectual disability dipilih karena berdasarkan beberapa hasil studi pendahuluan adalah salah satu ABK yang ditemui oleh peneliti di sekolah inklusi dan negeri adalah anak yang terdiagnosis maupun siswa yang memiliki karakteristik intellectual disability. Menurut Mangunsong (2009) siswa disabilitas intelektual 
dengan kategori ringan (skor IQ 55-70) banyak dijumpai pada sekolah umum. Peneliti juga pernah mendampingi beberapa anak dengan kategori disabilitas intelektual ringan pada sekolah inklusi. Sehingga semua guru harus lebih terampil menghadapi semua anak, termasuk guru pendidikan agama Islam.

Intelectual Disability (ID) merupakan salah satu jenis ABK yang masuk dalam kategori kelainan mental. ID yang dahulu disebut dengan istilah Tuna Grahita atau Retardasi mental merupakan suatu penurunan fungsi intelektual secara menyeluruh yang terjadi pada masa perkembangan (Hallahan \& Kauffman, 2006). Anak yang didiagnosis ID memiliki rendahnya kemampuan adaptif dalam berkomunikasi maupun ketrampilan sehari-hari. Anak ID memiliki kekurangan atau keterbatasan dari segi mental intelektual sehingga mengalami kesulitan dalam tugas-tugas akademik, komunikasi, maupun sosial.

Mengajar Pendidikan Agama Islam pada siswa dengan karakter Intellectual Disability memerlukan keahlian dari pengajar. Apabila siswa ini berada di dalam kelas inklusi, maka guru perlu melakukan modifikasi kurikulum. Modifikasi kurikulum ini telah berhasil meningkatkan keaktifan siswa disabilitas intelektual dalam mengikuti pembelajaran di kelas (D'Amico, 2010). Oleh karena itu, peneliti mendesain sebuah penelitian dengan melakukan pelatihan pada guru PAI untuk memodifikasi kurikulum menggunakan differentiated instruction pada mapel PAI untuk siswa disabilitas intelektual. Ada dua rumusan masalah dalam penelitian ini yaitu, bagaimana langkah langkah pelatihan modifikasi kurikulum menggunakan differentiated instruction untuk siswa disabilitas intelektual pada mapel PAI?; dan apakah pelatihan modifikasi kurikulum differentiated instruction untuk siswa disabilitas efektif meningkatkan pengetahuan dan ketrampilan guru PAI?.

Tujuan penelitian adalah untuk mengetahui dan menganalisis langkah-langkah penerapan pelatihan modifikasi kurikulum menggunakan differentiated instruction; serta untuk mengetahui apakah pelatihan efektif atau tidak dengan melihat adanya perbedaan antara pretest dan posttest pengetahuan tentang disabilitas intelektual dan pengetahuan modifikasi kurikulum differentiated instruction untuk siswa disabilitas intelektual pada mapel PAI. Manfaat teoritisnya meliputi peningkatan literatur tentang pengembangan bahan ajar dan metode pembelajaran bagi guru PAI untuk siswa berkebutuhan khusus. Selain itu juga Sebagai tambahan pengetahuan pada mata kuliah Psikologi Pendidikan dan Metodologi Pembelajaran. Sedangkan manfaat praktisnya bagi calon guru PAI adalah sebagai bekal saat menghadapi siswa berkebutuhan khusus terutama gangguan mental intellectual disability. Manfaat praktis bagi para pembaca adalah untuk menambah pengetahuan tentang desain Differentiated Instruction pada siswa ID. 


\section{TINJAUAN TEORITIS}

\section{Pelatihan Modifikasi Kurikulum Differentiated Instruction pada Mapel Pendidikan Agama Islam (PAI)}

Differentiated Instruction (DI) adalah sebuah pendekatan pengajaran dan pembelajaran bagi siswa dengan kemampuan beragam agar bisa belajar di kelas yang sama. DI diterapkan agar guru lebih mengenali siswa dari berbagai latar belakang pengetahuan, kesiapan, bahasa, kesiapan belajar, minat dan cara siswa bereaksi (Hall, 2002). Differentiated instruction berarti mengajarkan materi yang sama kepada semua siswa dengan menggunakan berbagai strategi pembelajaran atau membutuhkan guru yang dapat memberikan pelajaran pada berbagai tingkat kesulitan berdasarkan kemampuan masing-masing siswa. Guru yang melakukan differentiated instruction dapat mendiferensiasi: rancang pelajaran berdasarkan gaya belajar siswa, mengelompokkan siswa berdasarkan minat; topik atau kemampuan untuk tugas yang sama; menilai pembelajaran siswa menggunakan penilaian formatif, mengelola ruang kelas untuk menciptakan lingkungan yang aman dan mendukung; serta terus melakukan evaluasi dan menyesuaikan konten pelajaran untuk memenuhi kebutuhan siswa ('Amico, 2010).

Differentiated Instruction secara khusus merespon kemajuan belajar siswa secara berkelanjutan; apa yang telah mereka ketahui dan apa yang ingin mereka pelajari (Heacox, 2002) sehingga di dalam pembelajaran Differentiated Instruction, setiap siswa mendapatkan pembelajaran yang sesuai dengan kebutuhan mereka. Andini (2016) memaparkan ada empat karakteristik Differentiated Instruction, antara lain; (1) Pembelajaran diferensiasi bukanlah pembelajaran individual. Model pembelajaran dalam mengajar, seringkali guru akan mengajar pada "whole class" atau kelompokbesar, terkadang kelompok kecil dan terkadang secara individual dalam satu kelas. Variasei yang dilakukan ini sangat penting dalam meningkatkan pemahaman siswa dan ketrampilana juga membangun rasa kebersamaan; (2) Pembelajaran differensiasi bukanlah pembelajaran yang kacau. Guru yang menerapkan pembelajaran differensiasi akan mengatur dan memonitor kelas dengan menggunakan aktivas bersama-sama. Pembelajaran diferensuasu di kelas akan memberikan keefektifan tujuan pembelajaran siswa dan bukan kelas tanpa perencanaan atau ketidakdisiplinan; (3) Pada pembelajaran differensiasi kelompok tidak homogen tetapi bersifat fleksibel (Flexible Grouping). Pada kelas yang menerapkan pembelajaran differensiasi, kelompok yang dibentuk akan bersifat fleksibel dimana murid yang memiliki kekuatan dalam bidang tertentu akan bergabung dengan teman-teman lain dan bekerjasama dengan teman-temannya. Dalam pembelajaran differensiasi, kelompok akan selalu diubah-ubah berdasarkan kebutuhan dan pengalaman belajar siswa; (4) Pembelajaran differensiasi adalah proaktif dan berdasar pada asesmen. Pada kelas yang menerapkan pembelajaran ddiferensiasi, kita harus berfikir bahwa siswa-siswa memiliki kebutuhan belajar 
yang beragam dan berbeda satu dengan yang lainnya. Guru harus proaktif menemukan dan melakukan perencanaan dengan berbagai cara agar bisa mengekspresikan bagaimana siswa-siswanya bisa belajar.

Dasar menerapkan metode DI mengikuti aspek-aspek pada teori DI. Aspek-Aspek DI dibagi berdasarkan langkah membuat Differentiated Instruction. Dasar langkah langkah dalam DI meliputi teacher based method dan student based method (Tomlonson, 2001). Teacher based method terdiri dariKonten, Proses dan Product.Konten berhubungan dengan apa yang akan siswa ketahui, pahami dan yang akan dipelajari. Dalam konten ini, guru memodifikasi bagaimana setiap siswa mempelajari suatu topik pembelajaran. Bagi siswa yang tingkat kesiapannya sudah siap dan mengerti konten yang akan dipelajarinya, maka hal ini tidak masalah bahwa siswa belajar dengan konten yang sudah ditentukan. Namun bagi tingkat kesiapannya belum memahami konten tersebut, guru perlu melakukan modifikasi dan adaptasi berdasarkan tingkat kesiapan siswa tersebut. Aspek kedua adalah Proses.Proses berhubungan dengan cara murid mendapatkan informasi atau bagaimana seorang murid belajar. Dalam arti kata lain, proses adalah aktivitas murid dalam mendapatkan pengetahuan, pemahaman dan ketrampilan berdasarkan konten yang akan dipelajari. Aspek terakhir adalah Produk. Produk merupakan bukti apa yang sudah siswa pelajari dan pahami. Siswa siswa akan mendemonstrasikan atau mengaplikasikan mengenai apa yang sudah mereka pahami.

Aspek aspek DI berdasarkan student based method, terdiri dari: (a) kesiapan belajar (readiness). Kesiapan murid akan erat hubungannya dengan tingkat perkembangan pemahaman dan prestasi siswa di dalam kelas. Siswa yang memiliki kesiapan untuk belajar suatu hal yang mana sudah mempunyai pengetahuan mengenai apa yang akan dipelajari, memahaminya dan memiliki ketrampilan yang bagus, dipastikan akan sukses dan bisa mencapai tugas yang diberikan; (b) minat/ketertarikan (interest). Ketertarikan merupakan faktor terbesar dari dalam diri seseorang dalam memotivasi untuk belajar. jika tugas belajar yang diberikan dapat merangsang rasa ingin tahu dan gairah belajar siswa maka siswa akan memiliki perhatian yang tinggi pada belajar kemudian prestasi akan meningkat; (c) learning profile/profil belajar/gaya belajar.

Tugas belajar dapat mendorong siswa untuk bekerja dengan cara yang disukainya. Profil belajar anak akan dihubungkan dengan faktor sosial/emosi yaitu bahasa, budaya, kesehatan, kondisi keluarga dan kekhususan lainnya. Profil belajar berhubungan dengan gaya belajar/learning style. Ada beberapa siswa yang memiliki gaya belajar dengan visual (melihat, membaca), ada yang auditori (mendengarkan ceramah atau diskusi), ada juga yang memiliki gaya belajar kinestetik. Kecerdasan majemuk juga berhubungan dengan profil belajar. Kecerdasan majemuk Howard Gardner (dalam Syah, 2014) mendorong kita untuk meneliti sikap kita terhadap cara 
belajar Pendidikan Agama sehingga siswa dapat belajar dengan yang lebih nyaman. Kecerdasan majemuk yang dimaksud adalah kecerdasan visual, kecerdasan verbal, kecerdasan logis, ritmik/auditori, kinestetik, interpersonal, intrapersonal dan naturalis.

Berdasarkan aspek-aspek yang dijelaskan di atas, maka langkah-langkah dalam menerapkan DI adalah untuk memaksimalkan setiap kemampuan siswa dan tingkat keberhasilan dari setiap siswa, dimana guru akan membantu dalam proses pembelajaran tersebut. Langkah-langkahnya dijelaskan pada bagan di bawah ini:

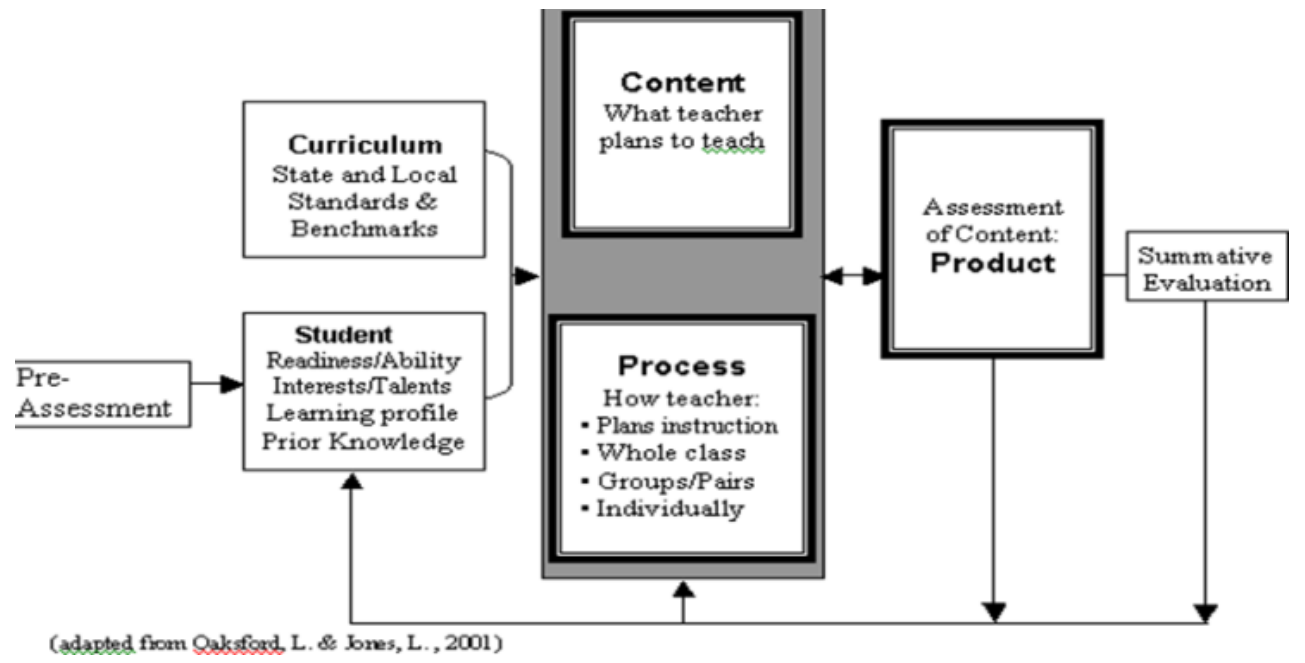

Bagan di atas menjelaskan proses pelaksanaan DI yaitu dengan guru melakukan asesmen awal dengan mengadakan pretest untuk mengetahui kemampuan dari masing-masing anak, sehingga guru bisa merencanakan, mendesain serta memodifikasi kurikulum.berdasarkan tingkat kesiapan anak, gaya belajar serta pengetahuan yang sudah didapat anak. Tingkat dari kemampuan belajar anak dibedakan menjadi tiga, antar lain:Independent Level (tingkat mandiri), anak pada tingkatan ini tidak memerlukan bantuan dan bisa mengerjakan tugas secara mandiri; Instructional Level (tingkat pemberian intruksi) anak pada tingkatan ini memerlukan bimbingan dalam memahami suatu konsep dan memerlukan bantuan dalam mengerjakan tugas; serta Frustation Level (tingkat frustasi), pada tingkatan ini anak sangat kesulitan dalam mengikuti pelajaran dikarenakan belum matangnya konsep konsep dasar serta pengetahuan yang dimiliki sehingga anak akan mudah menyerah dan frustasi dalam mengerjakan tugas.

Modifikasi Kurikulum menggunakan Differentiated Instruction akan diterapkan pada mata pelajaran PAI. Menurut Tafsir (dalam Muhaimin, 2005) Pendidikan Agama Islam adalah suatu kegiatan yang mendidikan agama islam. Pendidikan Agama Islam (PAI) merupakan salah satu bagian dari pendidikan islam (Muhaimin, 2005). PAI yaitu upaya mendidikan agama islam atau ajaran islam dan 
nilai-nilainya agar menjadi way of life (pandangan dan sikap hidup) seseorang. PAI dapat berwujud sebagai Segenap kegiatan yang dilakukan oleh seseorang untuk membantu seseorang/ kelompok peserta didik untuk menumbuhkan ajaran islam diwujudkan dalam sikap dan ketrampilan hidup sehari-hari dan peristiwa perjumpaan antara dua orang atau lebih yang hasilnya adalah tertanamnya ajaran Islam.

Tujuan umum PAI adalah untuk mencapai kualitas yang disebutkan oleh Al-Quran dan Hadits, sehingga pendidik PAI bertugas untuk membimbing dan mengarahkan anak didik supaya menjadi muslim yang teguh sebagai refleksi dari keimanan. Secara garis besar ruang lingkup PAI ada tiga bidang, yaitu aqidah, syariah dan akhlak. Aqidah adalah bidang keimanan dalam islam yang meliputi semua hal yang diyakini oleh seorang muslim. Syariah yaitu peraturan Allah yang mengatur hubungan manusia dengan Allah, sesama manusia dan alam seluruhnya. Akhlak adalah bagian dari agama islam yang mengatur tingkah laku manusia.

\section{Siswa Berkebutuhan Khusus Disabilitas Intelektual}

Intellectual disability atau disabilitas intelektual terdiri dari dua kata yaitu disabilitas dan intelektual. Intelektual padanan dari kata kecerdasan kognitif seseorang, sedangkan disabilitas adalah kondisi yang menggambarkan adanya disfungsi. Menurut Hallahan dan Kaufman (2006), disabilitas intelektual adalah istilah dari tuna grahita yang merupakan keterbatasan yang signifikan dalam berfungsi baik secara intelektual maupun secara adaptif. Karakteristik anak Disabilitas Intelektual (Mangunsong, 2009), adalah sebagai berikut: (a) Anak dengan skor IQ 55 - 70 tergolong ringan atau mild atau mampu didik. Anak dalamkategori ini masih bisa dididik di sekolah umum meskipun lebih rendah daripada anak normal pada umumnya.

Anak dengan disabilitas intelektual tidak memperlihatkan kelainan fisik yang mencolok walaupun perkembangan fisiknya sedikit agak lambat daripada anak rerata. Selain itu, anak dalam kategori ini kurang dalam hal kekuatan, kecepatan dan koordinasi serta memiliki masalah kesehatan. Rentang perhatian juga pendek sehingga sulit konsentasi dalam jangka waktu lama; (b) Anak dengan skor IQ tergolong sedang atau moderate, digolongkan sebagai anak yang mampu latih. Anak dengan disabilitas sedang/moderate mengalami hambatan pada koordinasi motorik. Ada juga keterbatasan dalam prestasi akademik, perawatan diri dan ketrampilan sosial. Anak dalam kategori ini pada umumnya masih perlu pengawasan yang konsisten dari orang lain; (c) Anak dengan skor IQ 25 - 40 tergolong berat atau severe. Anak membutuhkan pelayanan yang terus menerus dan pengawasan yan teliti; (d) Anak dengan skor IQ > 25 tergolong sangat parah atau profound. Anak pada kategori ini memiliki masalah yang serius baik menyangkut kondisi fisik serta inteligensi. Pada umumnya memperlihatkan kerusakan otak serta kelainan fisik yang nyata. 
Ciri-ciri umum anak dengan disabilitas intelektual antara lain: rentang perhatian yang rendah dan sering memusatkan perhatian pada benda yang salah; memiliki kesulitan mengingat suatu informasi; perkembangan bahasanya lambat mengalami kemajuan serta memiliki kosa kata yang terbatas; sesulitan mengatur tingkah lakunya sendiri atau regulasi diri yang rendah; sulit mendapat teman dan mempertahankan pertemanan; mudah mengalami putus asa karena sebesar apapun usaha yang dilakukan, akan mengalami kegagalan serta memiliki prestasi akademik yang rendah.

\section{Kerangka Berfikir}

Siswa yang menunjukkan ciri ciri atau sudah terdiagnosis menjadi siswa disabilitas intelektual termasuk ke dalam siswa frustation level. Siswa Disabilitas Intelektual membutuhkan perhatian dan metode belajar dari guru supaya dapat mengikuti pembelajaran di kelas. Metode differentiated instruction dipilih untuk dilatihkan pada guru PAI dalam mengajar siswa disabilitas intelektual di kelas. Sebelumnya Guru PAI tidak dibekali khusus untuk menjadi guru pendamping sehingga memodifikasi kurikulum menggunakan DI merupakan solusinya. Guru PAI tetap menggunakan kurikulum yang telah ditetapkan oleh sekolah, tetapi memodifikasi sesuai dengan kebutuhan siswa. Dalam pelatihan ini terdapat langkah-langkah bagaimana memodifikasi kurikulum yang sudah disiapkan guru pada kelas secara umumnya, kemudian dari aspek content, proses, product disesuaikan dengan adanya siswa karakteristik di kelas.

\section{Hipotesis}

Hipotesis dalam penelitian ini adalah skor posttest pengetahuan tentang disabilitas intelektual pada calon guru PAI meningkat secara signifikan dibandingkan dengan pretest. Hipotesis selanjutnya adalah skor posttest pengetahuan tentang modfifikasi kurikulum PAI menggunakan differentiated instruction pada calon guru PAI lebih tinggi daripada pretest. Kesimpulan hipotesisnya adalah pelatihan efektif meningkatkan pengetahuan tentang modifikasi kurikulum menggunakan differentiated instruction pada guru PAI.

\section{METODOLOGI}

\section{Desain Penelitian}

Desain penelitian yang digunakan adalah penelitian eksperimen dengan pendekatan kuantitatif dan kualitatif. Peneliti menggunakan desain eksperimen pretest posttest group desain. Desain eksperimen prestest posttestgroup merupakan desain eksperimen yang keberhasilannya diukur melalui tes yang dilaksanakan sebelum dan sesudah eksperimen (Latipun, 2006). Peneliti mengukur pengetahuan guru PAI tentang modifikasi kurikulum PAI untuk siswa disabilitas intelektual pada waktu sebelum pelatihan dan sesudah pelatihan. Metode eksperimen yang 
digunakan adalah metode pelatihan.

Metode pengumpulan data menggunakan lembar pretest dan posttest pengetahuan tentang differentiated instruction; lembar komitmen setelah pelatihan; lembar observasi pada saat pelatihan. Analisis data menggunakan analisis kuantitatif uji perbedaan skor nilai pretest dan posttest pengetahun tentang metode Differentiated Instruction untuk siswa DI pada mata pelajaran PAI.Tahapan penelitian akan dijabarkan melalui bagan di bawah in:

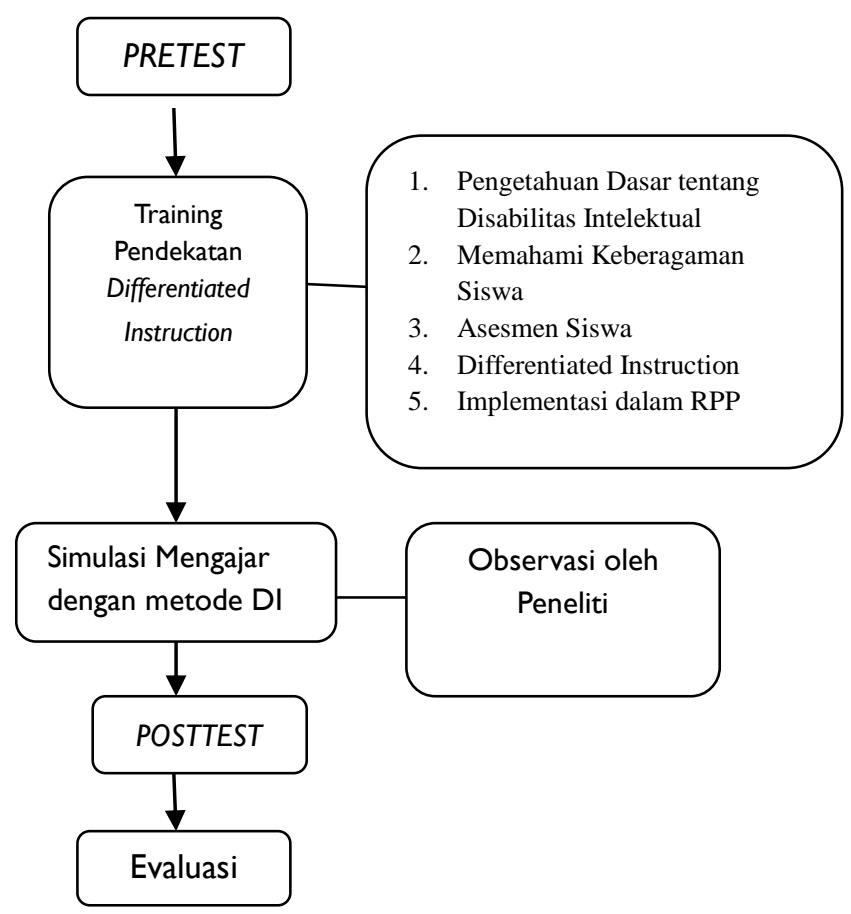

Lembar pengumpulan data selain angkat adalah wawancara dan observasi. Wawancara yang digunakan adalah wawancara semi terstruktur, sedangkan observasi dilakukan melalui observasi anekdotal. Penelitian dilaksanakan di Gedung F6 Fakultas Agama Islam, Universitas Muhammadiyah Yogyakarta, Jl. Ringroad Barat Kasihan Bantul Yogyakarta. Responden penelitian adalah alumni mahasiswa PAI FAI UMY yang memiliki pengalaman mengajar minimal satu tahun.

Penelitian ini menggunakan variabel pelatihan modifikasi kurikulum PAI menggunakan differentiated instruction untuk siswa disabilitas intelektual. Definisi operasional pelatihan modifikasi Kurikulum Differentiated Instuction pada mapel PAI untuk siswa disabilitas intelektual adalah pelatihan untuk memodifikasi kurikulum pada mapel PAI kelas V Sekolah dasar menggunakan pembelajaran berdiferensiasi untuk kelas yang terdapat siswa dengan karakteristik disabilitas intelektual. Pelatihan ini berdurasi 7 jam dengan metode ceramah, diskusi, praktek membuat differentiated kurikulum dengan kurikulum yang sudah disiapkan, presentasi dan evaluasi. Definisi operasional variabel selanjutnya adalah pengetahuan peserta mengenai differentiated instruction. Pengetahuan peserta 
mengenai differentiated instruction merupakan kumpulan informasi tentang differentitated instruction yang meliputi definisi serta langkah-langkahnya.

\section{Analisis Data}

Pada dasarnya tujuan utama penelitian ini adalah untuk menguji perbedaan prestest dan posttest pada sampel berpasangan. Metode analisis yang digunakan adalah analisis uji perbedaan parametrik aplikasi SPSS. Peneliti memilih uji t paired sampel t-test. Uji t paired sampel t-test adalah uji paramtris untuk mengukur signifikansi perbedaan antara dua kelompok data berpasangan (Sugiyono, 2016). Sebelum dilakukan uji t paired sampel, peneliti melakukan uji normalita sebagai syarat uji perbedaan parametrik.

\section{HASIL DAN PEMBAHASAN}

\section{Deskripsi}

Pelaksanaan pelatihan telah dilaksanakan pada hari kamis, 19 Juli 2018 di F6 002 pada pukul 08.00 - 14.00 WIB. Trainer pada pelatihan ini adalah Anita Aisah selaku peneliti dan staf pengajar prodi PAI FAI UMY. Trainer pertama ini memaparkan tentang disabilitas intelektual. Trainer selanjutnya adalah Admila Rosada. Admila adalah seorang pengajar di SD Inklusi sekaligus peneliti inklusi. Pelatihan ini diikuti oleh 19 peserta, yaitu guru PAI yang sudah mengajar minimal satu tahun. Namun ada satu peserta yang tidak mengikuti posttest karena ada cara, sehingga ada 18 peserta yang mengikuti pretest dan posttest.

Sesi pertama memulai modifikasi kurikulum adalah peserta dibekali pengetahuan tentang anak berkebutuhan khusus terutama definisi siswa disabilitas intelektual, karakteristik siswa Disabilitas Intelektual serta bagaimana mengajar siswa disabilitas intelektual. Trainer menggunakan metode ceramah interaktif. Peserta juga diajak diskusi bagaimana menghadapi siswa yang memiliki karakteristik disabilitas intelektual. Sesi kedua, peserta diajak untuk membuka wawasan tentang pendidikan inklusi. yaitu mengenal sekolah inklusi. Metode pada langkah kedua ini menggunakan metode ceramah aktif. Materi yang diberikan oleh trainer kedua adalah konsep dasar keberagaman serta mengenal keberagaman berdasar aspek mental salah satunya tuna grahita atau dengan istilah baru yaitu disabilitas intelektual.

Sesi ketiga adalah pemaparan tentang cara mengasesmen siswa. Trainer memberikan pengetahuan langkah mengasesmen siswa. Langkah asesmen siswa mulai dari mendeteksi kesiapan belajar siswa, minat belajar dan profil belajar (kecerdasan majemuk). Peserta diberikan kesempatan untuk praktek membuat asesmen siswa berdasarkan pengalaman mengajar maupun pengalaman praktek mengajar selama masih mahasiswa. Kesiapan belajar terdiri dari kesiapan belajar, kesiapan kemandirian dan kesiapan gaya belajar. Pada aspek minat belajar, peserta 
harus mendeteksi siswa yang antusias belajar PAI di dalam kelas. Siswa antusias memiliki indikator ikut aktif dalam pembelajaran serta dapat menjawab pertanyaan dengan tepat. Aspek terakhir pada asesmen siswa adalah profil belajar. Profil belajar diasesmen berdasarkan 8 kecerdasan majemuk Howard Gardner. Peserta diberikan blanko tabel seperti di bawah ini, kemudian diisi asesmen siswa yang pernah diajar.

Sesi keempat yaitu latihan memodifikasi kurikulum dengan manggunakan differentiated instruction. Pemateri mengawali dengan filosofi differentiated instruction, pemahaman yang salah tentang DI dan aspek-aspek DI. Aspek-aspek DI meliputi konten, proses, produk serta lingkungan belajar. Kurikulum yang digunakan pada praktek modifikasi kurikulum menggunakan DI adalah kurikulum mata pelajaran PAI dan Budi Pekerti, kelas V SD dengan tema Mengenal Allah dan Kitab-Kitabnya. Pada sesi ini, peserta pelatihan langsung praktek memodifikasi kurikulum PAI yang telah disediakan. Peserta dibagi menjadi dua kelompok besar, masing-masing kelompok terdiri dari 9 peserta. Peserta diberikan tugas oleh pemateri untuk memodifikasi konten. Proses dan produk berdasarkan salah satu asesmen siswa yang ditentukan. Modifikasi konten dan prosesnya harus mempertimbangkan strategi pembelajaran berdiferensiasi meliputi kooperatif, berbasis kelompok, berbasis tugas dan intruksi eksplisit. Variasi proses pelaksanaan pembelajaran dapat terjadi secara kelompok, klasikal, berdua maupun individu. Diskusi kelompok berlangsung selama 30 menit. Setiap kelompok diberikan RPP yang berbeda. Kelompok pertama diberikan tugas memodifikasi kurikulum RPP PAI kelas V SD dengan tema Mengenal Allah dan Kitab-Kitabnya. Kelompok kedua RPP PAI kelas V SD dengan tema Cita-Citaku Menjadi Anak Sholih.

Sesi kelima adalah presentasi kelompok. Semua kelompok mempresentasikan hasil diskusi. Hasil diskusi dari kelompok pertama adalah merubah metode pembelajaran. Karena siswa disabilitas intelektual tidak bisa mengikuti pembelajaran hanya dengan metode ceramah dan diskusi. Metode pembelajaran yang dilakukan adalah berkelompok atau berdua. Ada siswa yang menjadi peer tutor bagi siswa DI dalam mengenalkan asmaul husna. Selain itu modifiikasi selanjutnya adalah pada sumber belajar. Karena metode ditambahkan bernyanyi maka sumber belajar bisa dari youtube. Alat dan bahan juga ditambahkan alat dan bahan tiga dimensi agar siswa DI mudah memahami.

Evaluasinya dibagi menjadi 3 kategori utama, evaluasi untuk siswa mandiri, kemudian Evaluasi untuk DI dibagi menjadi dua kelompok yaitu evaluasi pada siswa DI yang bisa diberikan intruksi dan siswa DI yang kesulitan diberikan instruksi/frustation level. Presentasi pada kelompok dua adalah dimodifikasi metode mengajarnya. Pada RPP yang disediakan metode mengajarnya berupa melihat media. Pada modifikasi kali ini metode mengajarnya ditambah role play di depan kelas. Role play dilakukan dengan teman menjadi anak sholih di dalam rumah maupun di sekolah. Anak dengan indikator DI bisa mengikuti role play 
dengan arahan yang sederhana dari guru. Sehingga alat dan bahan juga menyesuaikan role play yang dilakukan. Evaluasinya hampir sama dengan presentasi kelompok sebelumnya yaitu dibagi menjadi tiga evaluasi yang berdasarkan tiga level.

\section{HASIL}

Pertanyaan dalam rumusan masalah adalah apakah ada perbedaan pengetahuan antara pretest dengan posttest pada peserta pelatihan modifikasi kurikulum PAI menggunakan Differentiated instruction pada mapel PAI untuk siswa Disabilitas Intelektual? Jawabannya adalah ada perbedaan yang signifikan, ditunjukkan dengan nilai sig 0,00 $(0,00<0,05)$. Mean Pretest adalah 54,47 sedangkan mean posttest adalah 81 . Hampir semua peserta mengalami kenaikan skor. Jumlah peserta yang mengikuti pelatihan adalah 19, tetapi ada 18 peserta yang dianalisis skor pretest dan posttestnya. Satu peserta tidak mengikuti posttest.

Pertanyaan kedua adalah bagaimana kertampilan yang didapat oleh peserta pada saat pelatihan? Peneliti tidak mengukur secara khusus ketrampilan setiap peserta. Ketrampilan setiap peserta direpresentasikan di dalam kelompok. Terdapat dua kelompok besar yaitu kelompok satu dan dua. Ketrampilan yang diharapkan adalah ketrampilan memodifikasi kurikulum Pendidikan Agama Islam. Hasil observasi pada proses pelatihan terkait dengan ketrampilan membuat DI dijelaskan pada tabel di bawah ini:

\begin{tabular}{|c|c|c|c|}
\hline No & Aspek & $\begin{array}{c}\text { Peserta Kelompok } 1 \\
\text { (10 Peserta) }\end{array}$ & $\begin{array}{c}\text { Peserta Kelompok } 2 \\
\text { (9 peserta) }\end{array}$ \\
\hline 1. & Asesmen Siswa & $\begin{array}{l}\text { Dapat melakukan asesmen } \\
\text { siswa dengan cara mengingat } \\
\text { nama siswa kemudian } \\
\text { mengaitkan kesiapan belajar, } \\
\text { kemandirian belajar dan profil } \\
\text { belajarnya. }\end{array}$ & $\begin{array}{l}\text { Dapat melakukan asesmen } \\
\text { siswa dengan cara mengingat } \\
\text { nama siswa kemudian } \\
\text { mengaitkan kesiapan belajar, } \\
\text { kemandirian belajar dan profil } \\
\text { belajarnya. } \\
\text { Kelompok dua belum } \\
\text { memahami sepenuuhnya } \\
\text { perbedaan siswa boderline } \\
\text { dengan disabilitas intelektual, } \\
\text { sehingga kesulitan memasukkan } \\
\text { karakteristiknya di dalam tabel } \\
\text { asesmen. }\end{array}$ \\
\hline 2. & $\begin{array}{l}\text { Memodifikasi } \\
\text { Kurikulum Berdasarkan } \\
\text { DI pada Mapel PAI } \\
\text { untuk siswa Disabilitas } \\
\text { Intelektual }\end{array}$ & $\begin{array}{l}\text { Pada saat presentasi, } \\
\text { modifikasi yang dilakukan } \\
\text { tidak dilakukan secara } \\
\text { berkesinambungan. } \\
\text { Modifikasi kurikulum } \\
\text { dilakukan pada metode } \\
\text { pembelajaran. } \\
\text { Penambahan metode } \\
\text { pembelajaran ini seharusnya }\end{array}$ & $\begin{array}{l}\text { Pada saat presentasi, modifikasi } \\
\text { yang dilakukan tidak dilakukan } \\
\text { secara berkesinambungan. } \\
\text { Modifikasi kurikulum dilakukan } \\
\text { pada metode pembelajaran. } \\
\text { Pemilihan metode } \\
\text { pembelajarannya menarik yaitu } \\
\text { metode role play dan dijelaskan } \\
\text { teknik role playnya. }\end{array}$ \\
\hline
\end{tabular}


juga ada modifikasi pada

aspek selanjutnya.

Pada aspek evaluasi tidak dijelaskan secara detail, bagaimana soal untuk setiap level yang ditentukan.
Penambahan metode pembelajaran ini seharusnya juga ada modifikasi pada aspek selanjutnya.

Pada aspek evaluasi tidak dijelaskan secara detail, bagaimana soal untuk setiap level yang ditentukan.

\section{DISKUSI}

Penelitian ini berjudul efektifitas pelatihan modifikasi kurikulum dengan pendekatan differentiated instruction pada mapel PAI untuk siswa Disabilitas Intelektual dari segi urutan materi sudah sesuai dengan aspek differentiated instruction. Berdasarkan Thomloson (2001), Differentiated instruction memiliki aspek yang berdasarkan dua karateristik yaitu student based method dan teacher based method. Pelatihan ini dimulai dengan pemberian pengetahuan tentang student based method yaitu asesmen siswa. Asesmen siswa berdasarkan gaya belajar, kemandirian belajar dan profil belajar. Profil belajar yang diajarkan juga langsung dikaitkan dengan Pendidikan Agama Islam. Sebagaimana yang dipaparkan oleh Muhaiman (2005), hakekat PAI adalah menumbuhkan ajaran islam diwujudkan dalam sikap dan ketrampilan sehari hari. Hakekat PAI ini langsung diterapkan pada pelatihan terutama aspek profil belajar.

Karakteristik differentiated instruction yang kedua adalah teacher based method (Thomloson 2001). Pelatihan ini juga dipaparkan aspek DI berdasarkan teacher based method yang meliputi konten, proses dan produk. Pemateri sudah menjelaskan konten, proses dan produk, tetapi hasil setelah dipraktekkan oleh peserta di dalam pelatihan tidak sesuai dengan teori yang disampaikan. Peserta tidak memodifikasi secara keseluruhan. Modifikasi hanya pada satu aspek yaitu proses, tetapi hasil dari modifikasi ini tidak dikaitkan dengan produk.

Teacher efficacy sangat mempengaruhi kemampuan untuk memodifikasi kurikulum menggunakan Differentiated Instruction (Dixon, 2014). Moon dkk (dalam Dixon 2014) menjelaskan bahwa alasan guru tidak melakukan differensiasi kurikulum untuk mengajar keragaman siswa adalah hampir 50\% guru tidak tahu mengapa dan bagaimana harus melakukan differensiasi. Pelatihan ini memiliki tujuan untuk menambah pengetahuan dan meningkatkana ketrampilan guru dalam mendiferensiasi kurikulum sehingga akan menumbuhkana teacher efficacy pada peserta pelatihan. Teacher efficacy dipengaruhi oleh kompetensi guru mulai dari pengetahuan sampai pada ketrampilan. Pelatihan ini bertujuan meningkatkan pengetahuan dan membentuk ketrampilan dalam membuat differentiated instruction khusus kelas yang terdapat siswa dengan karakteristik Disabilitas Intelektual. Asesmen dan diagnosis siswa disabilitas intelektual perlu dilakukan oleh pihak tertentu dan membutuhkan waktu yang panjang (Joyce dkk, 2015). Salah satu ciri 
terpenting siswa disabilitas intelektual adalah kemampuan berfikir siswa yang berada jauh di bawah rata-rata. Oleh karena itu perlu dipahami apabila peserta kesulitan memberikan karakteristik untuk siswa disabilitas intelektual di dalam lembar asesmen siswa. Hal ini juga didukung oleh hampir semua peserta mengajar di sekolah umum yang memiliki siswa dengan ciri-ciri hampir sama dengan ciri ciri siswa disabilitas intelektual. Joyce (2015), salah satu asesmen yang dilakukan untuk mendiagnosis siswa DI melalui tes intelegensi dan dilakukan oleh profesional, psikolog maupun dokter spesialis anak.

Hasil penelitian ini menunjukkan adanya peningkatan pengetahuan yang signifikan antara pretest dan posttest, ditunjukkan dengan nilai signifikansi 0,00 $(0,00<0,05)$. Namun penelitian ini tidak mengukur pretest dan posttest ketrampilan peserta dalam memodifikasi perilaku menggunakan differentiated instruction. Charismi (2016), menjelaskan salah satu pengukuran efektivitas pelatihan adalah membandingkan pretest dengan posttest atau membandingkan posttest dengan standar yang telah ditentukan. Pada pelatihan ini ketrampilan tidak dilakukan posttest sehingga tidak diketahui tingkat keberhasilan pelatihan. Selain itu waktu yang sangat terbatas (praktek pelatihan hanya 45 menit) tidak efektif dalam meningkatkan ketrampilan guru dalam memodifikasi kurikulum berdasarkan DI (Andini, 2016).

\section{SIMPULAN}

Simpulan pertama pada penelitian ini adalah ada peningkatan secara signifikan antara pretest dan posttest pengetahuan peserta terhadap modifikasi kurikulum berdasarkan differentiated Instruction pada mapel PAI untuk siswa disabilitas intelektual. Kesimpulan kedua adalah ketrampilan peserta dalam mengasesmen siswa masih belum optimal dan ketrampilan mengaplikasikan DI pada penerapannya di dalam kurikulum masih perlu ditingkatkan. Saran untuk peneliti selanjutnya adalah perlu dilakukan posttest ketrampilan memodifikasi kurikulum berdasarkan differentiated instruction secara individual/ setiap peserta untuk mengetahui efektifitas pelatihan. Selain itu perlu juga ditambahkan waktu pelatihan seperti penambahan waktu praktik implementasi DI pada RPP yang telah disediakan. Saran untuk peserta, peserta harus terus belajar agar dapat menerapkan hasil pelatihan secara optimal di dalam kelas.

\section{DAFTAR PUSTAKA}

Abdullah, N. 2013. Mengenal Anak Berkebutuhan Khusus. Magistra No.86 tahun XXV Desember 2013, ISSN 0215-9511. Diunduh dari http://bit.ly/2guOXOC

Andini, D. W. 2016. "Differentiated Instruction": Solusi Pembelajaran dalam Keberagaman Siswa di Kelas Inklusif. Trihayu: Jurnal Pendidikan Ke-SD-an, Vol 2, Nomor 3, Mei 2016, hlm 340 - 349.

Berkowitz M.W. \& Mary A. H. 2009. Character Education and Gifted Children. 
High Ability Studies, Vol 20. No. 2, December 2009, 131-142.

D’Amico, J. \& Kate G. 2010. Differentiated Instruction for Middle School Science Teacher, Activities and Strategies for an Inclusive Classroom. San Fransisco: John Wiley \& Sons, Inc.

Desmita. 2011. Psikologi Perkembangan Peserta Didik. Bandung: Remaja Rosdakarya.

Dixon, F. A., Yssel, N., McConnell, J. M., \& Hardin, T. (2014). Differentiated instruction, professional development, and teacher efficacy. Journal for the Education of the Gifted, 37(2), 111-127.

Fitriyani, A. L., 2013. Efektifitas Remedial Teaching PAI Dalam Meningkatkan Hasil Belajar Siswa: Studi Kuasi Eksperimen Pada Bahasan Sholat untuk Siswa Kelas VIII di SMP Negeri 3 Lembang Thn Ajaran 2012/2013. Thesis. Bandung: Fakultas Pendidikan Ilmu Sosial Universitas Pendidikan Indonesia.

Hall, T. (2002). Differentiated instruction. Wakefield, MA: National Center on.

Hallahan, D. P. \& Kauffman J. M. 2006. Exceptional Children: An Introduction to Special Education (10th Ed). Boston: Pearson.

Hamun, L.2014. Pembelajaran PAI Bagi Anak Berkebutuhan Khusus. Jurnal Pendidikan Agama Islam Vol XI, No.2 Desember 2014. Banda Aceh: Fakultas Tarbiyah UIN Ar-Raniry Banda Aceh.

Haq, A. H. B. 2016. Efikasi Diri Anak Berkebutuhan Khusus yang Berprestasi di Bidang Olahraga. JIPI, ISSN: 2301-8267, Vol 04 No.02 Agustus 2016. Diunduh dari http://bit.ly/2B0G9Y0k

Heacox, D. 2002. Differentiating Instruction in The Regular Classroom. USA: Free Spirit Publishing.

Indonesia, P. R. (2003). Undang-undang Republik Indonesia nomor 20 tahun 2003 tentang sistem pendidikan nasional. Jakarta: Pemerintah Republik Indonesia.

Joyce dkk. 2015. Guidence of Asesment and Diagnosis of Intellectual Disability in adulthood; A document Compiled by a Working Group of The British Psychological Society's Division of Clinical Psychology, Faculty for People with Intellectual Disability. Leicester: British Psychology Society.

Latipun. 2006. Psikologi Eksperimen. Malang: UMM Press Universitas Muhammadiyah Malang.

Maftuhin, M., \& Fuad, A. J. (2018). Pembelajaran Pendidikan Agama Islam Pada Anak Berkebutuhan Khusus. Journal An-Nafs: Kajian Penelitian Psikologi, 3(1), 83-98.

Mangunsong, F. 2009. Psikologi dan Pendidikan Anak Berkebutuhan Khusus Jilid 1. Jakaera: Lembaga Pengembangan Sarana Pengukuran dan Pendidikan Psikologi Universitas Indonesia.

Muhaimin. 2005. Pengembangan Kurikulum Pendidikan Agama Islam di Sekolah, Madrasah dan Perguruan Tinggi. Jakarta: PT: Raja Grafindo Persada. 
Pramuji, E. 2015. Metode Pembelajaran Pendidikan Agama Islam di SD Negeri Tanjung 1 Kecamatan Purwokerto Selatan Kabupaten Banyumas, Tahun Ajaran 2014/2015. Skripsi. Purwokerto: Program Studi Pendidikan Agama Islam Fakultas Tarbiyah dan Ilmu Keguruan IAIN Purwokerto.

Sugiyono. 2016. Metode Penelitian Kuantitatif. Bandung: CV Alfabeta

Suryosubroto, B. 2009. Proses Belajar Mengajar di Sekolah. Jakarta: Rineka Cipta.

Tafsir. 2010. Filsafat Pendidikan Islami. Bandung: PT Remaja Rosdakarya.

Taufiq, M. 2009. Penerapan Model Pembelajaran Klasikal dalam Pengajaran Membaca Alquran di SMP Muhammadiyah Surakarta. Skripsi. Surakarta: Fakultas Agama Islam Universitas Muhammadiyah Surakarta.

Tomlinson, CA., (2001). Differentiation of instruction in the elementary grades. ERIC Digest. 